(International Journal of Agriculture and Wildlife Science)
http://dergipark.org.tr/jaws

Araştırma Makalesi

\title{
Tuz Stresinin Börülcede Bazı Fizyolojik Özellikler ve Mineral Madde Oranlarına Etkisi $^{* *}$
}

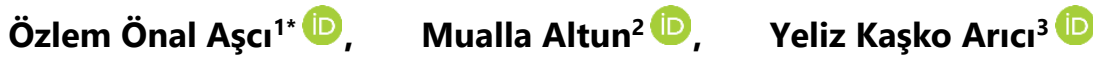 \\ ${ }^{1}$ Ordu Üniversitesi, Ziraat Fakültesi, Tarla Bitkileri Bölümü, Ordu \\ ${ }^{2}$ Ordu Üniversitesi, Fen Bilimleri Enstitüsü, Ordu \\ ${ }^{3}$ Ordu Üniversitesi, Tıp Fakültesi, Biyoistatistik ve Tıbbi Bilişim Anabilim Dalı, Ordu \\ Geliş tarihi (Received): 21.04.2021 Kabul tarihi (Accepted): 09.06.2021
}

\begin{abstract}
Anahtar kelimeler: Börülce, $\mathrm{NaCl}$, fotosentetik pigment, tolerans

Özet. Karagöz ve Ülkem börülce çeşitlerinde farklı tuz stresinin $(0,25,50,75$, 100, 125, 150, 175 ve 200 $\mathrm{mM} \mathrm{NaCl}$ ) bazı stres parametreleri üzerine etkisini belirlemek amacıyla saksı denemesi olarak yürütülen bu çalışma, tesadüf parsellerinde faktöriyel deneme desenine göre 4 tekrarlamalı olarak kurulmuştur. Araştırmada yaprak dokularında prolin, klorofil ( $a$, b ve toplam), karotenoid, fenolik madde miktarı, yaprağın oransal su içeriği ve yaprak dokusunun elektriksel iletkenliği, toprak üstü aksamın $\mathrm{Na}, \mathrm{Ca}, \mathrm{K}, \mathrm{P}$ içerikleri ile $\mathrm{K} \mathrm{Na}^{-1}$ ve $\mathrm{Ca} \mathrm{Na}{ }^{-1}$ oranı belirlenmiştir. Yapılan varyans analizi sonucunda, klorofil b, toplam klorofil ve karotenoid içerikleri üzerine tuz stresi ve çeşitlerin etkisi bulunmazken, incelenen diğer özelliklerin tuz stresinden etkilendiği belirlenmiştir. Araştırma sonucunda her iki çeşitte de tuz dozu arttıkça prolin sentezinin ve $\mathrm{Na}$ birikiminin arttığı $\mathrm{K} \mathrm{Na}^{-1}$ oranının azaldığı belirlenmiştir. Araştırmada hücre zarı stabilitesinin Karagöz çeşidinde $125 \mathrm{mM}$, Ülkem çeşidinde ise $150 \mathrm{mM}$ 'dan itibaren bozulduğu belirlenmiştir. $\mathrm{K} \mathrm{Na}^{-1}$ oranında ilk önemli azalış $25 \mathrm{mM}$ dozunda gerçekleşmiştir.

\section{*Sorumlu yazar}

onalozlem@hotmail.com
\end{abstract}

\section{The Effect of Salt Stress on Some Physiological Properties and Mineral Ratios in Cowpea}

\begin{tabular}{|c|c|}
\hline Keywords: & Abstract. In order to determine the effect of different salt stress $(0,25,50,75,100,125,150,175$ and \\
\hline $\begin{array}{l}\text { Cowpea, } \\
\text { photosynthetic pigment, } \\
\text { tolerance }\end{array}$ & $\begin{array}{l}200 \mathrm{mM} \mathrm{NaCl}) \text { on some stress parameters in cowpea } \mathrm{cv} \text {. Karagoz and Ulkem, this study, which was } \\
\text { conducted as a pot experiment, was established in } 4 \text { replications according to the factorial design with } \\
\text { randomized plots. In this study, proline, chlorophyll ( } \mathrm{a}, \mathrm{b} \text { and total), carotenoid, phenolic content, } \\
\text { relative water content and electrical conductivity of leaf, } \mathrm{Na}, \mathrm{Ca}, \mathrm{K}, \mathrm{P} \text { contents and } \mathrm{K} \mathrm{Na}^{-1} \text { and } \mathrm{Ca} \mathrm{Na}^{-1} \\
\text { ratio of the above ground parts of plants were determined. As a result of the analysis of variance, it was } \\
\text { determined that salt stress and varieties had no effect on chlorophyll b, total chlorophyll and carotenoid } \\
\text { contents, while the other traits examined were affected by salt stress. As a result of the research, it was } \\
\text { determined that as the salt dose increased in both cultivars, proline synthesis an } \mathrm{Na} \text { accumulation } \\
\text { increased and the } \mathrm{K} \mathrm{Na}^{-1} \text { ratio decreased. In the study, it was determined that cell membrane stability } \\
\text { deteriorated from } 125 \mathrm{mM} \text { in cv. Karagoz and } 150 \mathrm{mM} \text { in cv. Ulkem. The first significant decrease in the } \\
\mathrm{K} \mathrm{Na}^{-1} \text { ratio occured at the } 25 \mathrm{mM} \text {. }\end{array}$ \\
\hline
\end{tabular}

${ }^{* *}$ Çalışma Farklı NaCl konsantrasyonlarının bazı börülce (Vigna unguiculata L.) çeşitlerinde bitki gelişimine etkisi başlıklı Yüksek Lisans tezinden veriler içermektedir. 


\section{GiRiş}

Börülce taze baklaları sebze, vejetatif aksamı kaba yem, tohumları ise yemeklik tane baklagil veya kesif yem olarak değerlendirilebilen bir bitkidir. TÜiK verileri incelendiğinde, 2020 yılında 13.227 da alanda kuru baklagil, 18.420 da alanda ise sebze olarak yetiştiriciliğinin yapıldığı görülmektedir (Anonim, 2021). Börülce sıcaklığa ve kuraklığa dayanımı iyi olması (Çulha ve Bozoğlu, 2016) nedeniyle gelecek yıllarda ülkemizde öneminin daha da artacağı düşünülen bir bitkidir. Nitekim son yıllarda börülce ile ilgili yapılan bilimsel çalışmalar giderek artmaktadır. Ülkemizde börülcede bir yandan ıslah çalışmaları yapılarak farklı kullanım amaçlarına (sebze, yemeklik tane baklagil ve yemlik) uygun çeşitler geliştirilmekte, bir yandan da farklı ekolojilerde üretimi için agronomik çalışmalar yürütülmektedir.

Ülkemizde bitkisel üretimi sınırlayan faktörlerden birisi olan toprak tuzluluğunun yaklaşık 1.5 milyon ha alanı etkilediği (Çullu ve ark., 2015) bilinmekle birlikte, küresel iklim değişikliğine bağlı olarak Türkiye'de yaşanacak olan muhtemel kuraklık artışı (Özgen ve ark., 2015) devamında tuzluluk sorunun artmasına da neden olacaktır. Hem mevcut alanların daha etkin kullanımı hem de gelecekte doğru üretim planlamalarının yapılabilmesi için farklı tür ve çeşitlerin tuzluluğa tepkilerinin belirlenmesi gerekmektedir.

Tuz stresinin bitkilerde birçok olumsuz etkileri bulunmakta, bunlardan bir tanesinin klorofilin yapısını değiştirmek (Çulha ve Çakırlar, 2011) iken bir diğeri ise bitkide mineral madde alımını ve dengesini değiştirmektir. Zambi ve Önal Aşcı (2020), bezleye genotiplerinde tuz stresinin bitkilerin klorofil, fosfor, potasyum içeriği ile $\mathrm{K} \mathrm{Na}$ 1 oranını azalttığını, Ca ve Na konsantrasyonu arttırdığını belirlemişlerdir. Kaymak ve Acar (2020) ise tuz stresinin orman üçgülü yapraklarında klorofil a, klorofil b ve karotenoid içeriğini azalttığını bildirmişlerdir. Emirzeoğlu ve Başak (2020), tuz stresinin biber genotiplerinde yaprak oransal su içeriğini azalttığını, yaprak hücrelerinde membran zarı zararlanmasını arttırdığını bildirmişlerdir.

Bu çalışma Karagöz ve Ülkem börülce çeşitlerinde farklı toprak tuzluluğunun bazı fizyolojik özellikler ve mineral madde konsantrasyonuna etkisini belirlemek amacıyla yürütülmüştür.

\section{MATERYAL VE METOT}

Çalışma 2015 yılı Temmuz-Eylül döneminde saksı denemesi olarak Ordu Üniversitesi serasında yürütülmüştür. Araştırmada börülcenin (Vigna unguiculata L.) Karagöz ve Ülkem çeşitleri kullanılmıştır. Denemede her saksıya 4 mm elekten elenmiş, hava kurusu $2.5 \mathrm{~kg}$ tarla toprağı doldurularak bitkiler yetiştirilmiştir. Araştırmada kullanılan toprak kumlu tınlı tekstüre sahip, hafif alkali $\left(\mathrm{pH}:\right.$ 7.91) reaksiyonlu, tuzsuz $\left(0.18 \mathrm{dS} \mathrm{m}^{-1}\right)$ ve orta seviyede kireçlidir (\%5.3). Toprağın mineral içeriği incelendiğinde ise $\mathrm{N}$ içeriğinin çok az (\%0.013), P ve $\mathrm{K}$ bakımından yetersiz (sırasıyla 7.3 ve $64.6 \mathrm{mg} \mathrm{kg}^{-1}$ ), Fe ve Cu bakımından yeterli olduğu (sırasıyla 15.3 ve $5.7 \mathrm{mg} \mathrm{kg}^{-1}$ ), Mn içeriğinin az $\left(2.6 \mathrm{mg} \mathrm{kg}^{-1}\right)$ ve $\mathrm{Zn}$ içeriğinin ise yü $\mathrm{ksek}\left(7.6 \mathrm{mg} \mathrm{kg}^{-1}\right)$ olduğu anlaşılmaktadır.

Araştırma Tesadüf Parsellerinde Faktöriyel Deneme Desenine göre 4 tekrarlamalı olarak kurulmuş ve çeşitlere 9 farklı tuz konsantrasyonu $(0,25,50,75,100,125,150,175$ ve $200 \mathrm{mM} \mathrm{NaCl})$ uygulanmıştır. Çalışmada her saksıya 8 tohum ekilmiş, temel gübreleme amacıyla ekimle birlikte 50 ppm N $\left(\left(\mathrm{NH}_{4}\right)_{2} \mathrm{SO}_{4}\right), 100$ ppm P ve 125 ppm K $\left(\mathrm{KH}_{2} \mathrm{PO}_{4}\right)$ çözeltisi verilmiştir (Korkmaz, 2015).

Fidelerde 2. gerçek yapraklar çıkıı̆ında seyreltme yapılarak her saksıda 4 bitki bırakılmıştır. Bitkilerde 4. gerçek yapraklar görüldüğünde ilk tuz uygulamasına başlanılmış ve tuz şokundan kaçınmak için planlanan tuz dozları 2' şer gün arayla aşamalı olarak verilmiştir. Deneme süresince saf su ile sulama yapılarak toprağın nem içeriği sabit tutulmuştur. Bitkiler, tuz zararının şiddetli bir şekilde ortaya çıkması göz önüne alınarak, ilk tuz uygulamasından 16 gün sonra hasat edilmiştir. Hasat sırasında 0 ve $25 \mathrm{mM} \mathrm{NaCl}$ uygulanan bitkilerin generatif dönemde, diğer dozların uygulandığı bitkilerin ise vejetatif dönemde olduğu gözlenmiştir.

Yaprak dokularında prolin miktarı Bates ve ark. (1973)'nın bildirdiği yöntemle belirlenmiştir. Yaprak dokularının klorofil (klorofil a, klorofil b ve toplam klorofil) ve karotenoid içerikleri Turan (2012)'nin bildirdiği yöntemle hazırlanan örneklerde Lichtenthaler (1987)'e göre belirlenmiştir. Yaprak dokularının fenolik madde miktarı Beyhan ve ark. (2010)'nın bildirdiği yönteme göre belirlenmiştir.

Yaprağın oransal su içeriği Kuşvuran (2010)'nın bildirdiği şekilde belirlenmiştir.

Yaprak dokularının elektriksel iletkenliğini (EL) belirlemek için alınan yaprak diskleri $15 \mathrm{ml}$ deiyonize su içeren test tüplerinde $25^{\circ} \mathrm{C}$ de 2 saat inkube edilmiş ve çözeltinin elektriksel iletkenliği ölçülmüştür $\left(E C_{1}\right)$, ardından test tüpleri $100{ }^{\circ} \mathrm{C}$ de 10 dakika otoklavlanmış, $25^{\circ} \mathrm{C}$ ye kadar soğutulmuş ve çözeltinin tekrar elektriksel iletkenliği ölçülmüştür (EC2) (Hniličková ve ark., 2019).

$$
E L(\%)=\frac{E C 1}{E C 2} \times 100
$$


Mineral madde konsantrasyonu toprak üstü aksamda belirlenmiştir. Analizin yapılabilmesi için öncelikle kurutulan bitki aksamı öğütülmüştür. Öğütülen bitki örneklerinden alınan 200 mg materyal kül fırınında $550{ }^{\circ} \mathrm{C}^{\prime}$ de

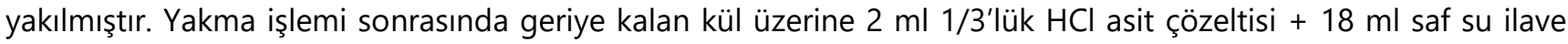
edilmiştir. Elde edilen karışım filtre kağıdından süzüldükten sonra mineral madde analizi için örnekler hazır hale gelmiştir (Akgün, 2015). Örneklerinin $\mathrm{Na}$ ve K içeriği Flame metrede, Ca içerikleri Atomik absorbsiyon spektrofotometrede, $\mathrm{P}$ içerikleri ise spektrofotometrede belirlenmiştir. $\mathrm{K} \mathrm{Na}^{-1}$ ve $\mathrm{Ca} \mathrm{Na}^{-1}$ oranı belirlenmiştir.

Verilerin normal dağııım kontrolü Shapiro-Wilk testi, alt grupların varyanslarının homojenlik kontrolü Bartlett's testi ile yapılarak, araştırmada elde edilen verilerden fenolik madde miktarı hariç diğer verilerin varyans analizine uygun oldukları belirlenmiştir. Fenolik madde mikarına ait veriler ise parametrik test varsayımlarını sağlamadığı için ANOVA öncesinde verilere Box-Cox transformasyonu yapılmıştır. Daha sonrasında araştırmada elde edilen tüm veriler Tesadüf Parsellerinde Faktöriyel Deneme Desenine göre analiz edilmiştir. Farklı ortalamaların belirlenmesinde Tukey's çoklu karşılaştırma testi kullanılmışır. Hesaplamalarda ve yorumlamalarda \%5 önem düzeyi kullanılmıştır. Tüm hesaplamalar Minitab 17 istatistik paket programı ile yapılmışırı.

\section{BULGULAR VE TARTIŞMA}

Yapılan varyans analizi sonucunda yaprağın oransal su içeriği (YOS, \%) bakımından çeşit $\times$ tuz dozu interaksiyonu istatistki olarak önemli $(p<0.001)$ bulunmuştur. Karagöz çeşidinde tuz stresi YOS'ta genellikle azaltıcı etki göstermekle birlikte belirlenen YOS bakımından tuz dozları arasında istatistiki olarak farklılık bulunmamıştır. Ülkem çeşidinde ise YOS önce artmış, sonra azalmış bu nedenle en yüksek YOS 75 mM, en düşük YOS ise 200 mM dozunda belirlenmiş ve söz konusu iki doz arasında istatistiki olarak önemli farklıık bulunmuştur. Tuz dozu bakımından sadece $75 \mathrm{mM}$ dozunda çeşitler arasında farklılık önemli olurken, diğer dozlarda ise YOS bakımından çeşitler arasında fark yoktur (Çizelge 1). Bilindiği üzere bitkiler tuz stresine maruz kaldıklarında öncelikle topraktan su alımı zorlaşmaktadır (Çulha ve Çakırlar, 2011). Abeer ve ark. (2015), çalışmamızla benzer olarak $200 \mathrm{mM}$ tuz uygulamasının börülcede YOS içeriğini kontrol bitkilerine göre önemli düzeyde azalttığını bildirmişlerdir. YOS bitkilerin su durumunu doğrudan yansıtır ve azalması tuz stresinin bitkilerde su açığının yaşandığını göstermektedir (Rahneshan ve ark., 2018). Çalışmamızda da YOS değerlerinde azalmanın gerçekleşmesi, $\mathrm{NaCl}$ stresinin börülce bitkilerinde su alımını azalttığını göstermektedir.

Çizelge 1. Farklı tuz dozlarında börülce yaprağında belirlenen oransal su içeriği (YOS) ve elektriksel iletkenlik (EL)*. Table 1. Relative water content (RWC) and electrical conductiivity (EC) in cowpea leaf determined under different salt doses.

\begin{tabular}{llll}
\hline Çeşit & Doz & YOS (\%) & EL (\%) \\
\hline & 0 & $93.19 \pm 1.03 \mathrm{Aa}$ & $17.90 \pm 1.81 \mathrm{BCa}$ \\
& 25 & $94.22 \pm 0.52 \mathrm{Aa}$ & $13.42 \pm 1.17 \mathrm{Ca}$ \\
Karagöz & 50 & $92.13 \pm 0.88 \mathrm{Aa}$ & $14.10 \pm 1.98 \mathrm{BCa}$ \\
& 75 & $89.75 \pm 1.02 \mathrm{Ab}$ & $16.65 \pm 2.07 \mathrm{BCa}$ \\
& 100 & $91.75 \pm 1.04 \mathrm{Aa}$ & $16.89 \pm 1.84 \mathrm{BCa}$ \\
& 125 & $90.28 \pm 2.65 \mathrm{Aa}$ & $26.77 \pm 0.94 \mathrm{ABa}$ \\
& 150 & $92.21 \pm 0.69 \mathrm{Aa}$ & $19.78 \pm 1.72 \mathrm{BCa}$ \\
& 175 & $89.42 \pm 1.02 \mathrm{Aa}$ & $33.76 \pm 9.52 \mathrm{Aa}$ \\
& 200 & $94.14 \pm 1.32 \mathrm{Aa}$ & $27.76 \pm 2.39 \mathrm{Aa}$ \\
& 0 & $91.42 \pm 0.60 \mathrm{ABa}$ & $22.75 \pm 1.13 \mathrm{ABa}$ \\
& 25 & $93.22 \pm 0.50 \mathrm{ABa}$ & $19.56 \pm 0.37 \mathrm{Ba}$ \\
Ülkem & 50 & $94.11 \pm 1.24 \mathrm{ABa}$ & $16.11 \pm 1.22 \mathrm{Ba}$ \\
& 75 & $96.22 \pm 1.82 \mathrm{Aa}$ & $17.93 \pm 1.52 \mathrm{Ba}$ \\
& 100 & $92.56 \pm 0.94 \mathrm{ABa}$ & $14.20 \pm 1.41 \mathrm{Ba}$ \\
& 125 & $95.13 \pm 0.41 \mathrm{ABa}$ & $21.44 \pm 0.56 \mathrm{ABa}$ \\
& 150 & $91.59 \pm 0.13 \mathrm{ABa}$ & $29.879 \pm 1.871 \mathrm{Aa}$ \\
& 175 & $93.04 \pm 0.71 \mathrm{ABa}$ & $24.683 \pm 4.519 \mathrm{ABa}$ \\
& 200 & $89.48 \pm 1.51 \mathrm{Ba}$ & $25.549 \pm 4.561 \mathrm{ABa}$ \\
& Çeşit: & 0.060 & 0.642 \\
& Doz: & 0.598 & 0.000
\end{tabular}

*Veriler Ortalama \pm Standart Hata şeklinde sunulmuştur.

Aynı sütunda ortak büyük harfi olmayan doz ortalamaları arasındaki fark istatistiksel olarak önemlidir $(p<0.05)$.

Aynı sütunda ortak küçük harfi olmayan çeşit ortalamaları arasındaki fark istatistiksel olarak önemlidir $(p<0.05)$. 
Tuz stresi bitki hücre zarının yapısını etkileyerek, zarın akışkanlığını ve geçirgenliğini değiştirmektedir (Çulha ve Çakırlar, 2011). Stres çalışmalarında hücre zarı geçirgenliğinin göstergesi olarak, yaprak dokularının elektriksel iletkenliği (EL) belirlenmekte ve bitkilerin tuza toleransının belirlenmesinde en önemli seçim kriterlerinden birisi olduğu bildirilmektedir (Ashraf ve Ali, 2008). Araştırmada elde edilen EL değerlerine yapılan istatistik analiz sonucunda çeşit $\times$ tuz dozu interaksiyonu istatistiki olarak önemli $(p<0.05)$ bulunmuştur. Karagöz çeşidinde 125 mM ve üzeri tuz dozları, Ülkem çeşidinde ise $150 \mathrm{mM}$ ve üzeri tuz dozlarında hücre zarının iletkenliğinin kontrole göre arttığı anlaşılmaktadır (Çizelge 1). Hücre zarının iletkenliğinin artması hücre içi elektrolitlerin özellikle Ca ve K olmak üzere bazı iyonların hücre dışına çıkmasına neden olarak, hücre içi iyon dengesini bozmaktadır (Tuna ve Eroğlu, 2017). Bu durum bize çeşitlerde ifade edilen dozlara kadar membran stabilitesinin korunabildiğini göstermektedir. Bununla birlikte aynı tuz dozlarında hücre zarı iletkenliği bakımından çeşitler arasında bir farklıık olmadığı anlaşıımaktadır.

Yapılan varyans analizi sonucunda, klorofil a bakımından çeşit $\times$ tuz dozu interaksiyonu önemli $(p<0.05)$ bulunurken, klorofil b, toplam klorofil ve karotenoid değerleri bakımından çeşitler ve tuz dozları arasında farklıık bulunmamaktadır. Klorofil a içeriği bakımından çeşitlerin verdiği tepkiler incelendiğinde, tuz uygulamasının Ülkem çeşidinde klorofil a'nın azalmasına neden olduğu, ancak bu azalışın istatistiki olarak önemli olmadığı anlaşılmaktadır. Karagöz çeşidinde ise 175 ve 200 mM tuz dozunun klorofil a içeriğinde azalışa neden olduğu görülmektedir. Çeşitlerin aynı tuz dozlarına verdikleri tepkiler ise istatistiki olarak farksızdır. Tuz uygulaması her iki çeşitte de klorofil b, toplam klorofil ve karotenoid içeriğinde artış ve azalışlara neden olmakla birlikte tüm $\mathrm{NaCl}$ dozlarında belirlenen klorofil b, toplam klorofil ve karotenoid içeriği kontrol bitkilerinde belirlenen değerlerle benzer bulunmuştur (Çizelge 2). Bu durum bize klorofil a'nın klorofil b ve karotenoid pigmentlerine göre tuz stresine karşı daha hassas olduğunu göstermektedir. Bizim çalışmamızdan farklı olarak Manaf ve Zayed (2015), yaptıkları bir çalışmada sulama suyu tuzluluğu arttıkça börülcede klorofil a, klorofil b, toplam klorofil ve karotenoid içeriğinin arttığını belirlemişlerdir.

Çizelge 2. Farklı tuz dozlarında börülce çeşitlerinde belirlenen fotosentetik pigmentler*. Table 2. Photosynthetic pigments determined in cowpea varietes with different salt doses.

\begin{tabular}{|c|c|c|c|c|c|}
\hline Çeşit & Doz & $\begin{array}{l}\text { Klorofil a } \\
\left(\mathrm{mcg} \mathrm{cm}^{-2}\right)\end{array}$ & $\begin{array}{l}\text { Klorofil b } \\
\left(\mathrm{mcg} \mathrm{cm}^{-2}\right)\end{array}$ & $\begin{array}{l}\text { Toplam klorofil } \\
\left(\mathrm{mcg} \mathrm{cm}^{-2}\right)\end{array}$ & $\begin{array}{l}\text { Karotenoid } \\
\left(\mathrm{mcg} \mathrm{cm}^{-2}\right)\end{array}$ \\
\hline & 0 & $15.47 \pm 2.18 \mathrm{ABa}$ & $7.70 \pm 1.23$ & $23.16 \pm 3.35$ & $5.35 \pm 0.56$ \\
\hline & 25 & $12.26 \pm 4.50 \mathrm{ABa}$ & $8.38 \pm 4.88$ & $20.63 \pm 9.37$ & $3.85 \pm 0.58$ \\
\hline & 50 & $12.86 \pm 1.78 \mathrm{ABa}$ & $6.44 \pm 1.00$ & $19.301 \pm 2.77$ & $4.74 \pm 0.37$ \\
\hline & 75 & $28.47 \pm 5.13 \mathrm{Aa}$ & $21.69 \pm 7.04$ & $50.17 \pm 11.64$ & $6.14 \pm 0.99$ \\
\hline \multirow[t]{9}{*}{ Karagöz } & 100 & $18.29 \pm 2.78 \mathrm{ABa}$ & $7.65 \pm 1.05$ & $25.94 \pm 3.81$ & $6.21 \pm 0.86$ \\
\hline & 125 & $16.14 \pm 4.41 \mathrm{ABa}$ & $9.75 \pm 3.27$ & $25.89 \pm 7.49$ & $6.00 \pm 0.65$ \\
\hline & 150 & $17.22 \pm 4.94 \mathrm{ABa}$ & $10.893 \pm 4.26$ & $28.11 \pm 8.99$ & $6.89 \pm 0.61$ \\
\hline & 175 & $7.41 \pm 2.20 \mathrm{Ba}$ & $7.13 \pm 3.80$ & $14.54 \pm 5.13$ & $4.79 \pm 1.24$ \\
\hline & 200 & $9.68 \pm 3.46 \mathrm{Ba}$ & $9.20 \pm 2.65$ & $18.88 \pm 5.09$ & $5.54 \pm 0.65$ \\
\hline & 0 & $22.65 \pm 3.00 \mathrm{Aa}$ & $8.79 \pm 0.63$ & $31.44 \pm 3.50$ & $6.54 \pm 0.64$ \\
\hline & 25 & $13.12 \pm 3.34 \mathrm{Aa}$ & $7.62 \pm 1.93$ & $20.74 \pm 5.27$ & $4.05 \pm 0.89$ \\
\hline & 50 & $20.60 \pm 2.49 \mathrm{Aa}$ & $12.34 \pm 2.89$ & $32.94 \pm 4.07$ & $5.10 \pm 0.93$ \\
\hline & 75 & $20.62 \pm 0.30 \mathrm{Aa}$ & $11.27 \pm 1.29$ & $31.88 \pm 0.99$ & $5.54 \pm 0.87$ \\
\hline \multirow[t]{5}{*}{ Ülkem } & 100 & $15.47 \pm 1.86 \mathrm{Aa}$ & $9.16 \pm 1.67$ & $24.63 \pm 3.28$ & $4.47 \pm 0.54$ \\
\hline & 125 & $17.31 \pm 1.13 \mathrm{Aa}$ & $9.45 \pm 0.85$ & $26.76 \pm 1.80$ & $6.58 \pm 0.72$ \\
\hline & 150 & $8.99 \pm 2.01 \mathrm{Aa}$ & $5.55 \pm 0.67$ & $14.54 \pm 2.54$ & $4.18 \pm 0.46$ \\
\hline & 175 & $20.89 \pm 2.67 \mathrm{Aa}$ & $12.90 \pm 2.50$ & $33.80 \pm 5.13$ & $6.60 \pm 0.45$ \\
\hline & 200 & $19.20 \pm 4.62 \mathrm{Aa}$ & $9.39 \pm 2.05$ & $28.59 \pm 6.67$ & $6.31 \pm 1.44$ \\
\hline \multirow[t]{3}{*}{ P-Değeri } & Çeşit: & 0.153 & 0.852 & 0.465 & 0.958 \\
\hline & Doz: & 0.077 & 0.331 & 0.165 & 0.108 \\
\hline & Çeşit×Doz: & $0.033^{*}$ & 0.306 & 0.095 & 0.126 \\
\hline
\end{tabular}

*Veriler Ortalama \pm Standart Hata şeklinde sunulmuştur.

Aynı sütunda ortak büyük harfi olmayan doz ortalamaları arasındaki fark istatistiksel olarak önemlidir ( $p<0.05)$.

Aynı sütunda ortak küçük harfi olmayan çeşit ortalamaları arasındaki fark istatistiksel olarak önemlidir $(p<0.05)$.

Yapılan varyans analizi sonucunda yaprağın fenolik madde miktarı bakımından çeşit $\times$ tuz dozu interaksiyonu istatistiki olarak önemli $(p<0.01)$ bulunmuştur. Karagöz çeşidinde artan tuz dozları genellikle fenolik madde miktarını artıııken, Ülkem çeşidinde ise $125 \mathrm{mM}$ ve üzerinde belirlenen fenolik madde miktarının kontrol grubundan daha az olduğu belirlenmiştir. Ancak her iki çeşitte de fenolik madde miktarı bakımından tuz dozları aynı grupta yer almıştır. Çeşitlerin aynı tuz dozlarındaki fenolik madde miktarları bakımından sadece $150 \mathrm{mM}$ 
dozunda fark bulunmaktadır (Çizelge 3). Bitkilerde fenolik bileşiklerin birçok antioksidan enzim için serbest radikal temizleyicileri ve substratlar olarak işlev gördükleri bildirilmektedir (El_Mashad ve Mohamed 2012). Çalışmada kullanılan Karagöz çeşidinde fenolik madde miktarının çoğunlukla yüksek olması, Karagöz çeşidinde tuz stresine karşı savunma mekanizmasında fenolik maddenin etkili bir bileşik olduğunu düşündürmektedir. Ülkem çeşidinde ise artan tuz dozlarının fenolik madde miktarını genellikle azaltıcı etki yapmış olması söz konusu çeşitte fenolik maddelerin sentezinin tuz stresinden olumsuz etkilendiğini göstermektedir. Çalışmamızdan farklı olarak El_Mashad ve Mohamed (2012), düşük dozlarda NaCl uygulamasının börülce yapraklarında önemli derecede fenolik madde birikimini arttırdığını, 100 ve $150 \mathrm{mM} \mathrm{NaCl}$ uygulamasının ise azalttığını bildirmişlerdir. Bu durum çalışmada kullanılan çeşitlerin farklılı̆ından kaynaklanmaktadır.

Çizelge 3. Farklı tuz dozlarında börülce çeşitlerinde belirlenen fenolik madde ve prolin miktarı*.

Table 3. The amount of phenolic substance and proline determined in cowpea varietes with different salt doses.

\begin{tabular}{|c|c|c|c|}
\hline Çeşit & Doz & $\begin{array}{l}\text { Fenolik madde miktarı } \\
\text { (mg gallik asit } \mathrm{kg}^{-1} \text { yaş örnek ) }\end{array}$ & $\begin{array}{l}\text { Prolin } \\
\text { (mg g } \\
\text { (maş örnek) }\end{array}$ \\
\hline & 0 & $58.76 \pm 2.97 \mathrm{Aa}$ & $22.33 \pm 4.14 \mathrm{Ca}$ \\
\hline & 25 & $80.19 \pm 14.77 \mathrm{Aa}$ & $27.40 \pm 1.84 \mathrm{BCa}$ \\
\hline & 50 & $86.65 \pm 17.97 \mathrm{Aa}$ & $41.78 \pm 3.57 \mathrm{ABCa}$ \\
\hline & 75 & $68.79 \pm 5.34 \mathrm{Aa}$ & $45.34 \pm 3.12 \mathrm{ABCa}$ \\
\hline \multirow[t]{9}{*}{ Karagöz } & 100 & $81.07 \pm 18.24 \mathrm{Aa}$ & $50.21 \pm 3.44 \mathrm{ABCa}$ \\
\hline & 125 & $76.01 \pm 5.07 \mathrm{Aa}$ & $53.18 \pm 4.25 \mathrm{ABCa}$ \\
\hline & 150 & $93.30 \pm 8.46 \mathrm{Aa}$ & $57.22 \pm 4.70 \mathrm{ABCa}$ \\
\hline & 175 & $55.54 \pm 1.27 \mathrm{Aa}$ & $60.59 \pm 4.70 \mathrm{ABCa}$ \\
\hline & 200 & $73.81 \pm 10.15 \mathrm{Aa}$ & $73.36 \pm 13.52 \mathrm{Aba}$ \\
\hline & 0 & $98.16 \pm 8.08 \mathrm{Aa}$ & $15.67 \pm 0.56 \mathrm{Da}$ \\
\hline & 25 & $76.47 \pm 11.21 \mathrm{Aa}$ & $20.35 \pm 4.29 \mathrm{CDa}$ \\
\hline & 50 & $107.27 \pm 17.82 \mathrm{Aa}$ & $27.20 \pm 3.21 \mathrm{BCDa}$ \\
\hline & 75 & $95.04 \pm 11.28 \mathrm{Aa}$ & $36.44 \pm 1.98 \mathrm{BCDa}$ \\
\hline \multirow[t]{5}{*}{ Ülkem } & 100 & $91.00 \pm 2.44 \mathrm{Aa}$ & $50.08 \pm 2.17 \mathrm{BCa}$ \\
\hline & 125 & $79.38 \pm 14.13 \mathrm{Aa}$ & $54.11 \pm 4.69 \mathrm{Ba}$ \\
\hline & 150 & $52.83 \pm 5.84 \mathrm{~A} \mathrm{~b}$ & $51.16 \pm 5.16 \mathrm{BCa}$ \\
\hline & 175 & $63.57 \pm 4.77 \mathrm{Aa}$ & $56.54 \pm 9.42 \mathrm{Ba}$ \\
\hline & 200 & $75.91 \pm 3.53 \mathrm{Aa}$ & $111.02 \pm 22.37 \mathrm{Aa}$ \\
\hline \multirow[t]{3}{*}{ P-Değeri } & Çeşit: & 0.155 & 0.748 \\
\hline & Doz: & 0.084 & 0.000 \\
\hline & Çeşit×Doz: & $0.006^{* *}$ & $0.018^{*}$ \\
\hline
\end{tabular}

*Veriler Ortalama \pm Standart Hata şeklinde sunulmuştur.

Aynı sütunda ortak büyük harfi olmayan doz ortalamaları arasındaki fark istatistiksel olarak önemlidir $(p<0.05)$.

Aynı sütunda ortak küçük harfi olmayan çeşit ortalamaları arasındaki fark istatistiksel olarak önemlidir $(p<0.05)$.

Yapılan varyans analizi sonucunda prolin miktarı bakımından çeşit $\times$ tuz dozu interaksiyonu istatistiki olarak önemli $(p<0.05)$ bulunmuştur. Her iki çeşitte de tuz dozunun artmasıyla birlikte bitkide sentezlenen prolin miktarı artmış ve $75 \mathrm{mM}$ tuz dozunda sentezlenen prolin miktarı kontrol bitkilerine göre 2 kat artış göstermiştir (Çizelge 3). Prolinin hücre zarı bütünlüğünün sağlayarak ozmotik dengenin korunmasında önemli rol oynadığı bilinmektedir (Tuna ve Eroğlu, 2017). Araştırmamızda 25 mM tuz dozundan itibaren prolin sentezinin artması, çalışılan çeşitlerde tuz stresine karşı savunma mekanizması olarak prolin sentezinin önemli rol oynadığını göstermektedir. Nitekim çalışmamızda belirlenen elektriksel iletkenlik değerleri (Çizelge 1) ile prolin miktarlarındaki değişim birbiriyle uyumlu bulunmaktadır. Çalışmamızla benzer olarak Manaf ve Zayed, (2015) börülcede sulama suyu tuzluluğu arttıkça bitkide prolin miktarının arttığını bildirmiş̧lerdir.

Araştırmada toprak üstü aksamda belirlenen $\mathrm{Na}, \mathrm{K}$, Ca ve $\mathrm{P}$ konsantrasyonu verilerine yapılan varyans analizi sonucunda; çeşit $\times$ tuz dozu interaksiyonu istatistiki olarak önemli $(p<0.001)$ bulunmuştur. Her iki çeşitte de tuz uygulaması toprak üstü aksamda Na birikimine neden olmuştur. Bu durum bize incelenen çeşitlerin topraktan almış oldukları Na'u toprak üstü aksamda biriktirme eğiliminde olduğunu göstermektedir. Çalışmamızla benzer olarak Patel ve ark. (2010) tuz uygulamasının börülcede yaprakta Na birikimine neden olduğunu belirtmektedir. Ancak yüksek tuz dozlarında çeşitlerin toprak üstü aksamlarında biriktirilen Na miktarları birbirinden farklı olmuştur. Yüksek dozlarda Ülkem çeşidinin Karagöz çeşidine göre toprak üstü aksamda daha fazla Na biriktirdiği belirlenmiştir. Bununla birlikte yüksek dozlarında Ülkem çeşidinin EL (Çizelge 1) ve klorofil a (Çizelge 2) değerlerinin Karagöz çeşidine göre daha az olumsuz etkilenmesi, muhtemelen Ülkem çeşidinin Na iyonlarını Karagöz çeşidine göre vakuolde daha fazla depolamasından kaynaklanmaktadır. 
Çizelge 4 incelendiğinde görüleceği üzere her iki çeşitte tuzlu şartlarda topraktan $\mathrm{K}$ alımını devam ettirmişlerdir. Bilindiği üzere toprakta fazla bulunan $\mathrm{Na}^{+}$bitkilerin $\mathrm{K}$ alımını engellemektedir (Çulha ve Çakırlar, 2011). Nitekim, Turan ve ark. (2010), tuz stresinin mısırda K oranını hem kökte hem de gövdede azalttığını bildirmiştir. Kuşvuran ve ark. (2008) ise kavun genotiplerinde tuz stresi altında bazı genotiplerde K oranının azaldığını bazı genotiplerde ise arttığını bildirmiştir. K hücrede osmolit olarak görev aldığından (Çulha ve Çakırlar, 2011), K alımı hem yaprak oransal su içeriğinin korunması hem de K'un görev aldığı diğer biyokimyasal olayların devamlıı̆ı açısından önemlidir. Tuz stresi altında bitkinin $\mathrm{K}$ alımına devam edebilmesi bitkiyi Na'un olumsuz etkilerinden korumaktadır (Daşgan ve ark., 2002).

Çizelge 4. Farklı tuz dozlarında börülce çeşitlerinde belirlenen $\mathrm{Na}, \mathrm{K}, \mathrm{Ca}, \mathrm{P}$ konsantrasyonu ve $\mathrm{Ca} \mathrm{Na}^{-1 *}$. Table 4. $\mathrm{Na}, \mathrm{K}, \mathrm{Ca}, \mathrm{P}$ concentration and $\mathrm{Ca} \mathrm{Na}{ }^{-1}$ determined in cowpea varietes with different salt doses.

\begin{tabular}{lllllll}
\hline Çeşit & Doz & $\mathbf{N a}(\mathbf{p p m})$ & $\mathbf{K}(\mathbf{p p m})$ & $\mathbf{C a}(\%)$ & $\mathbf{P}(\%)$ & $\mathbf{C a ~ N a}^{-1}$ \\
\hline & 0 & $148.6 \pm 12.8 \mathrm{Da}$ & $826.0 \pm 102.6 \mathrm{Ca}$ & $1.42 \pm 0.16 \mathrm{Ba}$ & $0.14 \pm 0.02 \mathrm{ABa}$ & $95.16 \pm 5.67 \mathrm{Aa}$ \\
& 25 & $905.1 \pm 270.6 \mathrm{CDa}$ & $1318.0 \pm 96.3 \mathrm{BCa}$ & $2.18 \pm 0.06 \mathrm{ABa}$ & $0.21 \pm 0.02 \mathrm{Aa}$ & $30.31 \pm 7.49 \mathrm{Ba}$ \\
& 50 & $871.9 \pm 263.3 \mathrm{CDa}$ & $1135.0 \pm 116.0 \mathrm{Ca}$ & $2.07 \pm 0.22 \mathrm{ABa}$ & $0.22 \pm 0.03 \mathrm{Aa}$ & $33.91 \pm 14.59 \mathrm{Ba}$ \\
& 75 & $1096.5 \pm 461.6 \mathrm{BCDa}$ & $1189.0 \pm 273.8 \mathrm{Ca}$ & $2.03 \pm 0.23 \mathrm{ABa}$ & $0.15 \pm 0.03 \mathrm{ABa}$ & $33.03 \pm 15.38 \mathrm{Ba}$ \\
Karagözz & 100 & $2240.6 \pm 389.2 \mathrm{BCDa}$ & $2198.0 \pm 4676.0 \mathrm{Ba}$ & $2.25 \pm 0.25 \mathrm{ABa}$ & $0.13 \pm 0.01 \mathrm{ABa}$ & $10.52 \pm 1.26 \mathrm{Ba}$ \\
& 125 & $6434.5 \pm 443.9 \mathrm{Aa}$ & $3276.0 \pm 168.7 \mathrm{Aa}$ & $3.07 \pm 0.54 \mathrm{Aa}$ & $0.11 \pm 0.04 \mathrm{ABa}$ & $4.71 \pm 0.70 \mathrm{Ba}$ \\
& 150 & $2516.5 \pm 158.6 \mathrm{BCDa}$ & $1667.0 \pm 108.4 \mathrm{BCa}$ & $1.32 \pm 0.39 \mathrm{Ba}$ & $0.09 \pm 0.01 \mathrm{Ba}$ & $5.40 \pm 1.65 \mathrm{Ba}$ \\
& 175 & $4898.0 \pm 1238.8 \mathrm{ABa}$ & $2096.0 \pm 45.5 \mathrm{Ba}$ & $2.35 \pm 0.35 \mathrm{ABa}$ & $0.11 \pm 0.04 \mathrm{ABa}$ & $5.40 \pm 1.47 \mathrm{Ba}$ \\
& 200 & $3864.5 \pm 295.5 \mathrm{ABCb}$ & $1464.0 \pm 21.4 \mathrm{BCa}$ & $1.62 \pm 0.08 \mathrm{Bb}$ & $0.06 \pm 0.01 \mathrm{Bb}$ & $4.28 \pm 0.42 \mathrm{Ba}$ \\
& 0 & $300.0 \pm 67.6 \mathrm{Ca}$ & $792.0 \pm 83.6 \mathrm{Ba}$ & $1.09 \pm 0.10 \mathrm{Ca}$ & $0.11 \pm 0.01 \mathrm{Ba}$ & $46.39 \pm 15.45 \mathrm{Ab}$ \\
& 25 & $431.4 \pm 70.7 \mathrm{Ca}$ & $797.0 \pm 63.8 \mathrm{Ba}$ & $1.47 \pm 0.07 \mathrm{Ca}$ & $0.13 \pm 0.02 \mathrm{ABa}$ & $36.56 \pm 5.11 \mathrm{ABa}$ \\
& 50 & $1125.6 \pm 146.0 \mathrm{Ca}$ & $756.0 \pm 114.2 \mathrm{Ba}$ & $1.57 \pm 0.15 \mathrm{Ca}$ & $0.11 \pm 0.00 \mathrm{Ba}$ & $14.41 \pm 1.78 \mathrm{ABa}$ \\
& 75 & $1667.0 \pm 328.2 \mathrm{~B} \mathrm{Ca}$ & $890.7 \pm 39.3 \mathrm{ABa}$ & $2.15 \pm 0.17 \mathrm{BCa}$ & $0.13 \pm 0.02 \mathrm{Ba}$ & $13.91 \pm 2.63 \mathrm{ABa}$ \\
Ülkem & 100 & $2572.7 \pm 603.5 \mathrm{~B} \mathrm{Ca}$ & $1232.6 \pm 110.9 \mathrm{ABa}$ & $2.31 \pm 0.16 \mathrm{BCa}$ & $0.12 \pm 0.01 \mathrm{ABa}$ & $10.11 \pm 1.81 \mathrm{ABa}$ \\
& 125 & $2813.3 \pm 341.2 \mathrm{BCb}$ & $1100.0 \pm 52.9 \mathrm{ABb}$ & $2.33 \pm 0.18 \mathrm{BCa}$ & $0.11 \pm 0.01 \mathrm{Ba}$ & $8.54 \pm 0.88 \mathrm{Ba}$ \\
& 150 & $5021.5 \pm 3095.3 \mathrm{ABa}$ & $988.0 \pm 181.6 \mathrm{ABa}$ & $2.06 \pm 0.31 \mathrm{BCa}$ & $0.08 \pm 0.01 \mathrm{Ba}$ & $6.90 \pm 2.28 \mathrm{Ba}$ \\
& 175 & $8699.3 \pm 79.8 \mathrm{Aa}$ & $1548.0 \pm 446.8 \mathrm{ABa}$ & $3.23 \pm 0.84 \mathrm{ABa}$ & $0.15 \pm 0.03 \mathrm{ABa}$ & $3.73 \pm 0.98 \mathrm{Ba}$ \\
& 200 & $8297.3 \pm 1245.1 \mathrm{Aa}$ & $1990.7 \pm 383.5 \mathrm{Aa}$ & $4.28 \pm 0.33 \mathrm{Aa}$ & $0.26 \pm 0.07 \mathrm{Aa}$ & $5.37 \pm 0.79 \mathrm{Ba}$ \\
& Çeşit: & 0.012 & 0.000 & 0.081 & 0.726 & 0.018
\end{tabular}

*Veriler Ortalama \pm Standart Hata şeklinde sunulmuştur.

Aynı sütunda ortak büyük harfi olmayan doz ortalamaları arasındaki fark istatistiksel olarak önemlidir $(p<0.05)$.

Aynı sütunda ortak küçük harfi olmayan çeşit ortalamaları arasındaki fark istatistiksel olarak önemlidir $(p<0.05)$.

Çizelge 4 incelendiğinde, düşük tuz stresi altında yetişen Karagöz çeşidinin toprak üstü aksamında Ca oranının arttığı, yüksek tuz dozlarında ise Ca oranının azalmaya başladığı görülmektedir. Ülkem çeşidinde ise tuz dozu arttıkça Ca oranı sürekli artmıştır. Bununla birlikte tuz stresinin bitkilerde Ca alımını azalttığı bildirilmiştir (Doğru ve Canavar, 2020). Ancak bizim araştırmamızda ise genel durumdan farklı olarak bitkinin Ca oranı artmıştır. Çalışmamızda incelenen çeşitlerin yüksek tuz uygulamalarında dahi toprak üstü aksamda yüksek Ca oranına sahip olabilmeleri, bitkilerin yüksek tuz dozlarında bünyelerinde Na birikimine rağmen topraktan Ca almaya devam ettikleri anlamına gelmektedir. Kalsiyum bitki hücre zarlarının yapısal ve işlevsel bütünlüğünü korumada önemli rol oynar, hücre duvarı yapılarını stabilize eder, iyon taşınmasını ve seçiciliğini düzenler, hücre duvarı enzim aktivitesini ve iyon değişimini kontrol eder (Hadi ve Karimi, 2012). Bitkilerin tuz stresinde topraktan Ca alabilmeleri hücre zarı bütünlüğünü koruyabildiklerini göstermektedir. Nitekim Ca oranı ile elektriksel iletkenlik değerleri (Çizelge 1) birbirini desteklemektedir.

Çizelge 4'ten anlaşılacağı üzere, her iki çeşitte de tuz dozları karşısında bitkinin P oranı artış ve azalışlar göstermiştir. Karagöz çeşidinde düşük tuz dozlarında bitkinin topraktan P alımı artmışken, tuz dozu arttıkça topraktan alınan P miktarı da azalmıştır. Ülkem çeşidinde ise çok yüksek tuz dozlarında P oranı artış göstermiştir. Turan ve ark. (2010), tuz stresinin mısırda hem kökte hem de gövde de P oranının artmasına neden olduğunu bildirmiştir.

Yapılan varyans analizi sonucunda; toprak üstü aksamda hesaplanan $\mathrm{K} \mathrm{Na}^{-1}$ oranı bakımından çeşitler arasında ve tuz dozları arasında istatistiki olarak önemli (sırasıyla; $p<0.01$ ve $p<0.001$ ) farklılık olduğu belirlenmiştir. Karagöz çeşidinin $\mathrm{K} \mathrm{Na}^{-1}$ oranı (1.50) Ülkem çeşidinden (0.93) önemli derecede yüksek bulunmuştur. En yüksek K $\mathrm{Na}^{-1}$ oranı kontrol grubunda belirlenirken, $25 \mathrm{mM}$ tuz dozunda $\mathrm{K} \mathrm{Na}^{-1}$ oranı önemli derecede azalmış, uygulanan 
tuz dozu arttıkça $\mathrm{K} \mathrm{Na}^{-1}$ oranı giderek azalmıştır. Artan tuz dozlarında bitkilerin bünyelerine almış oldukları $\mathrm{K}^{+}$ve $\mathrm{Na}^{+}$artmakla birlikte $\mathrm{Na}^{+}$alımının $\mathrm{K}^{+}$alımından daha fazla olması nedeniyle (Çizelge 4) $\mathrm{K} \mathrm{Na}^{-1}$ oranı tuz stresinde azalmıştır (Şekil 1). Farklı bitkilerle yapılan çalışmalarda tuz stresinin bitkide $\mathrm{K} \mathrm{Na}^{-1}$ oranını azalttığı bildirilmiştir (Yağmur ve ark., 2006; Karakullukçu ve Adak, 2008; Zambi ve Önal Aşcl, 2020).

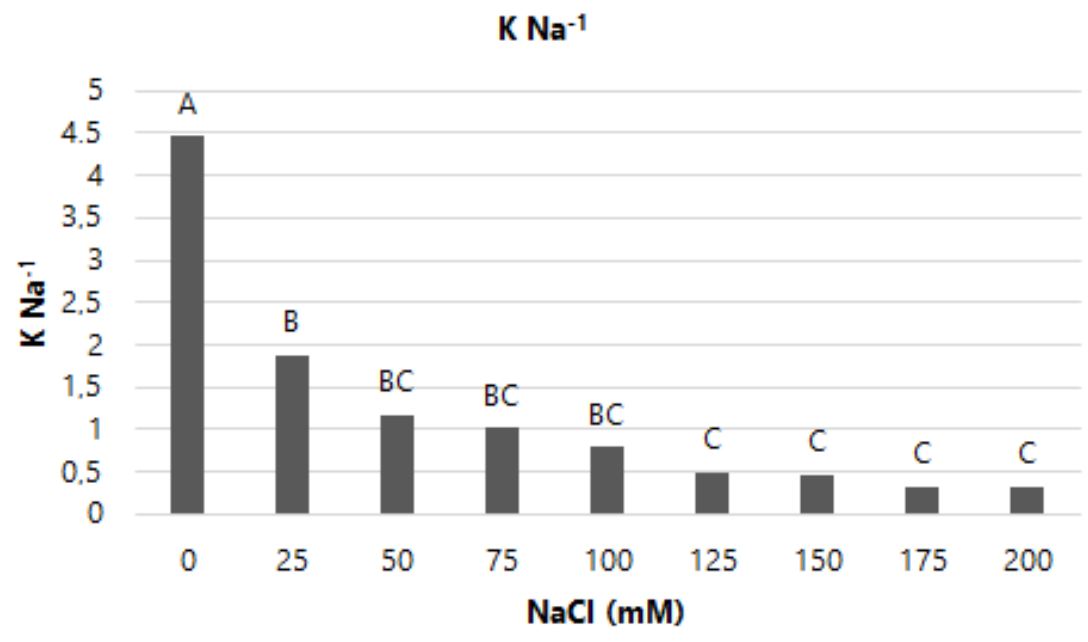

Şekil 1. Farklı tuz dozlarında toprak üstü aksamın $\mathrm{K} \mathrm{Na}^{-1}$.

Figure 1. $\mathrm{K} \mathrm{Na}^{-1}$ of the above ground components in different salt doses.

Ortak büyük harfi olmayan doz ortalamaları arasındaki fark istatistiksel olarak önemlidir $(p<0.05)$.

\section{SONUÇ}

Araştırma sonucunda toprak tuzluluğunun börülcede yaprak oransal su içeriğini (YOS), yaprak dokularında hücre zarı iletkenliğini (EL) önemli derecede etkilediği, YOS'un bütün tuz dozlarında her iki çeşitte de \%89'un üzerinde tutulabildiği, Karagöz çeşidinde 125 mM'a Ülkem çeşidinin ise 150 mM'a kadarki tuz dozlarında hücre zarı stabilitesinin korunabildiği belirlenmiştir. Bununla birlikte börülcede tuz stresinin fotosentetik pigmentlerden sadece klorofil a'yı istatistiki olarak önemli derecede etkilediği, klorofil b, toplam klorofil ve karetonoid pigmentlerinin tuz stresinden etkilenmediği belirlenmiştir. Bu nedenle klorofil a'nın diğer fotosentetik pigmentlere göre tuz stresine karşı daha hassas olduğu düşünülmüştür. Araştırmada tuz stresi karşısında Karagöz çeşidinde fenolik madde sentezinin genellikle arttığı, Ülkem çeşidinde ise genellikle azaldığı bu nedenle de Karagöz çeşidinde fenolik madde sentezinin tuz stresine tepkide etkisinin olduğu düşünülmüştür. Araştırmada her iki çeşitte de bitkilerin maruz kaldığı tuz dozu arttıkça sentezlenen prolin miktarı da artmıştır. Bu durum börülcede tuz stresine karşı prolin sentezinin önemli bir savunma mekanizması olduğunu göstermektedir. Araştırmada incelenen çeşitlerin tuzlu koşullarda topraktan aldıkları Na'u toprak üstü aksamda depoladıkları, K, Ca ve P alımını devam ettirebildikleri belirlenmiştir. Ancak, toprak üstü aksamda $\mathrm{K} \mathrm{Na}^{-1}$ ve $\mathrm{Ca} \mathrm{Na}^{-1}$ oranı tuz stresi altında korunamamış, tuz dozu arttıkça söz konusu oranlar giderek azalmıştır. $\mathrm{K} \mathrm{Na}^{-1}$ oranında ilk azalma $25 \mathrm{mM}$ dozunda yaşanmışırı. Tüm bu bilgilerin sonucunda börülcede tuz stresine karşı verilen tepkilerin değerlendirilmesinde klorofil a, prolin ve $\mathrm{K} \mathrm{Na}^{-1}$ oranın incelenmesinin uygun olacağı sonucuna varılmıştır.

\section{ÇIKAR ÇATIŞMASI}

Yazarlar arasında herhangi bir çıkar çatışması yoktur.

\section{YAZAR KATKISI}

Özlem ÖNAL AŞCl araştırmanın planlanması, yürütülmesi ve yayına dönüştürülmesinde, Mualla ALTUN araştırmanın yürütülmesi, verilerin elde edilmesinde, Yeliz KAŞKO ARICI verilere istatistik analiz yapılmasında ve analizin yorumlanmasında katkı sağlamışır. 


\section{TEŞEKKÜR}

Makalede sunulan verilerin bir kısmı Mualla ALTUN'un yüksek lisans tezinde yer almaktadır. Araştırma ODÜ BAP birimi tarafından TF 1531 nolu proje olarak desteklenmiştir. Ayrıca denemede kullanılan tohumları sağlayan Prof. Dr. İlknur AYAN ve prolin analizinde destek veren Doç. Dr. Elvan ÜSTÜN'e çok teşekkür ederiz.

\section{KAYNAKLAR}

Abeer, H., Abd_Allah, E. F., Alqarawi, A. A., \& Egamberdieva, D. (2015). Induction of salt stress tolerance in cowpea [Vigna unguiculata (L.) Walp.] by arbuscular mycorrhizal fungi. Legume Research, 38(5), $579-588$.

Akgün, M. (2015). Yerel mısır (Zea mays L.) genotiplerinin fosfor kullanım etkinliğinin belirlenmesi. Yüksek Lisans Tezi, Ordu Üniversitesi, Fen Bilimleri Enstitüsü, Ordu.

Ashraf, M., \& Ali, Q. (2008). Relative membrane permeability and activities of some antioxidant enzymes as the key determinants of salt tolerance in canola (Brassica napus L.). Environmental and Experimental Botany, 63, 266-273.

Bates, L. S., Waldren, R. P., \& Teare, I. D. (1973). Rapid determination of free proline for water-stress studies. Plant and Soil, 39, 205-207

Beyhan, Ö., Elmastaş, M., \& Gedikli, F. (2010). Total phenolic compounds and antioxidant capacity of leaf, dry fruit and fresh fruit of feijoa (Acca sellowiana, Myrtaceae). Journal of Medicinal Plants Research, 4(11), 1065-1072.

Emirzeoğlu, C, \& Başak, H . (2020). Orta Anadolu biber genotiplerinin farklı tuz konsantrasyonlarına tolerans düzeylerinin belirlenmesi. Uluslararası Tarım ve Yaban Hayatı Bilimleri Dergisi, 6(2) , 129-140.

Çulha, Ş., \& Çakırlar, H. (2011). Tuzluluğun bitkiler üzerine etkileri ve tuz tolerans mekanizmaları. Afyon Kocatepe Üniversitesi Fen Bilimleri Dergisi, 11, 11-34.

Çulha, G., \& Bozoğlu, H. (2016). Farklı kültürel uygulamalarla yetiştirilen amazon ve sırma börülce çeşitlerinin verim ve verim özellikleri. Tarla Bitkileri Merkez Araştırma Enstitüsü Dergisi, 25, 177-183.

Çullu, M. A., Kıııç, Ş., Şenol, S., Ağca, N., Kurucu, Y., Akça, E., Özcan, H., Aydın, G., Aksoy, E., Bilgili, A. V., Şahin, Y., Küsek, G., Sarı, M., Bayramin, I., Dinç, U., Kapur, S., \& Kanber, R. (2015). Türkiye'de toprak tuzlulaşmasından etkilenen alanlar ve haritalanması. Türkiye Ziraat Mühendisliği VIII. Teknik Kongresi, Ankara.

Dasgan, H. Y., Aktas, H., Abak, K., \& Cakmak, I. (2002). Determination of screening techniques to salinity tolerance in tomatoes ve investigation of genotype responses. Plant Science, 163, 695-703.

Deveci, M., \& Tuğrul, B. (2017). Ispanakta tuz stresinin yaprak fizyolojik özelliklerine etkisi. Akademik Ziraat Dergisi, 6, 89-98.

Doğru, A., \& Canavar, S., (2020). Bitkilerde tuz toleransının fizyolojik ve biyokimyasal bileşenleri. Academic Platform Journal of Engineering and Science, 8(1), 155-174.

Eker, S., Cömertpay, G., Konuşkan, Ö., Ülger, A. C., Öztürk, L., \& Çakmak, I. (2006). Effect of salinity stress on dry matter production and ion accumulation in hiybrid maize varietes. Turkish Journal of Agriculture and Forestry, 30(5), 365-373

Karakullukçu, E., \& Adak, M. S. (2008). Bazı nohut (Cicer arietinum L.) çeşitlerinin tuza toleranslarının belirlenmesi. Tarım Bilimleri Dergisi, 14(4), 313-319.

El-Mashad, A. A. A., \& Mohamed, H. I. (2012). Brassinolide alleviates salt stress and increases antioxidant activity of cowpea plants (Vigna sinensis). Protoplasma, 249, 625-635.

Hadi, M. R., \& Karimi, N. (2012). The role of Ca in plants' salt tolerance. Journal of Plant Nutrition, 35(13), 2037-2054.

Hniličková, H., Hnilička, F., Orsák, M., \& Hejnák, V. (2019): Effect of salt stress on growth, electrolyte leakage, $\mathrm{Na}^{+}$and K+ content in selected plant species. Plant Soil and Environment, 65, 90-96.

Kaymak, G., \& Acar, A. (2020). Orman üçgülü (Bituminaria bituminosa L.) genotiplerinin tuzluluğa dayanıklılık düzeylerinin belirlenmesi. Anadolu Tarım Bilimleri Dergisi, 35(1), 51-58.

Korkmaz, K., 2015. Sözlü görüşme. Ordu Üniversitesi Ziraat Fakültesi Toprak Bilimi ve Bitki Besleme Bölümü.

Kuşvuran, Ş., Yaşar, F., Abak, K., \& Ellialtıoğlu, ş. (2008). Tuz stresi altında yetiştirilen tuza tolerant ve duyarlı Cucumis sp.'nin bazı genotiplerinde lipid peroksidasyonu, klorofil ve iyon miktarlarında meydana gelen değişimler. Yüzüncü Yıl Üniversitesi Ziraat Fakültesi Tarım Bilimleri Dergisi, 18(1), 13-20

Kuşvuran, Ş. (2010). Kavunlarda kuraklık ve tuzluluğa toleransın fizyolojik mekanizmaları arasındaki bağlantılar. Doktora Tezi, Çukurova Üniversitesi, Fen Bilimleri Enstitüsü, Adana. 
Kuşvuran, Ş., (2011). Bamya (Abelmoschus esculentus L.)da tuz stresine tolerans bakımından genotipsel farklılıklar ve tarama parametrelerinin araştırılması. Batı Akdeniz Tarımsal Araştırma Enstitüsü Derim Dergisi, 28(2), 55-70.

Lichtenthaler, H. K. (1987). Chlorophylls and carotenoids: pigments of photosynthetic biomembranes. In L. Packer, \& R. Douce (Eds.), Methods in Enzymology, 148, Plant Cell Membranes, Newyork. USA: Academic Press

Manaf, H. H., \& Zayed, M. S. (2015). Productivity of cowpea as affected by salt stress in presence of endomycorrhizae and Pseudomonas fluorescens. Annals of Agricultural Sciences, 60(2), 219-226.

Minitab. (2010). Minitab 17. State College, Pennsylvania.

Özgen, A. M., Adak, M. S., Ulukan, H., Benlioğlu, B., Peşkircioğlu, M., Koyuncu, N., Yıldız, A., \& Tuna, D. E. (2015). iklim değişikliği ve bitkisel gen kaynakları. Türkiye Ziraat Mühendisliği VIII. Teknik Kongresi, Ankara.

Patel, P. R., Kajal, S. S., Patel, V. R., Patel, V. J., \& Khristi, S. M. (2010). Impact of salt stress on nutrient uptake and growth of cowpea. Brazilian Journal of Plant Physiology, 22(1), 43-48.

Rahneshan, Z., Nasibi, F., \& Moghadam, A. A. (2018). Effects of salinity stress on some growth, physiological, biochemical parameters and nutrients in two pistachio (Pistacia vera L.) rootstocks. Journal of Plant Interactions, 13(1), 73-82.

Tetiktabanlar, i. (2011). Tuz stresinin bezelyede (Pisum sativum L.) fenolik bileşikler üzerine etkisi. Yüksek Lisans Tezi, Gaziosmanpaşa Üniversitesi, Fen Bilimleri Enstitüsü, Tokat.

Toplaoğlu, K. (2010). Tuz stresinin chili biberlerinin pigment ve kapsaisinoid değişimi ile peroksidaz aktivitesi arasındaki ilişki. Yüksek Lisans Tezi, Çukurova Üniversitesi, Fen Bilimleri Enstitüsü, Adana.

Tuna, A., \& Eroğlu, B. (2017). Tuz stresi altındaki biber (Capsicum annuum L.) bitkisinde bazı organik ve inorganik bileşiklerin antioksidatif sisteme etkileri. Anadolu Tarım Bilimleri Dergisi, 32(1), 121-131.

Turan, M. A., Elkarim, A. H. A., Taban, N., \& Taban, S. (2010). Effect of salt stress on growth and ion distribution and accumulation in shoot and root of maize plant. African journal of Agricultural Research, 5(7), 584-588.

Turan, Ö. (2012). Nohut çeşitlerinde düşük sıcaklığa dayanıklıı̆ın fizyolojik, biyokimyasal ve moleküler düzeyde incelenmesi. Doktora Tezi, Hacettepe Üniversitesi, Fen Bilimleri Enstitüsü, Ankara.

TÜiK. (2021). Bitkisel üretim istatistikleri. http://www.tuik.gov.tr/PreTablo.do?alt_id=1001. Erişim tarihi: 19 Nisan 2021.

Yağmur, M., Kaydan, D., \& Okut, N. (2006). Potasyum uygulamasının tuz stresindeki arpanın fotosentetik pigment içeriği, ozmotik potansiyel, K+ /Na+ oranı ile bitki büyümesine etkileri. Tarım Bilimleri Dergisi, 12(2), 188-194.

Zambi, H., \& Önal Aşcl, Ö. (2020). NaCl stresinin yem bezelyesinin klorofil ve mineral içeriğine etkisi. Uluslararası Tarım ve Yaban Hayatı Bilimleri Dergisi, 6(3), 562-569. 